\title{
IL-1及 Genetic Polimorphism in Menopause Women as Periodontal Disease Risk Factor
}

\author{
Justine Tanjaya ${ }^{1}$, Elza Ibrahim Auerkari ${ }^{2}$ \\ ${ }^{1}$ Undergraduate Program, Faculty of Dentistry, Universitas Indonesia, Jakarta 10430, Indonesia \\ ${ }^{2}$ Department of Oral Biology, Faculty of Dentistry, Universitas Indonesia, Jakarta 10430, Indonesia \\ Correspondence e-mail to: j_tanjaya@yahoo.com
}

\begin{abstract}
Periodontal disease is a disease with multifactorial etiology that can occur in postmenopausal women. Objective: This research aims to know the description of the genetic polymorphism of IL- $1 \beta$ in postmenopausal women in Indonesia as a risk factor for periodontal disease. Methods: This study is a descriptive study on 55 biological stored amples. Sample's extracted DNA was analysed for polymorphisms IL $-1 \beta^{+3954}$ using PCR-RFLP method with Taq ${ }^{\alpha} 1$ restriction enzyme digests then the result was electroforized. Research results were analyzed using chi square test. Results: The genotype CC frequency was $85.7 \%$, CT $14.3 \%$, and TT was absent in normal people. CC $86.5 \%$, CT $8.3 \%$, and TT did not exist in people who have periodontal disease. Conclusion: Genetic polymorphisms IL-1 $\beta$ in Indonesia's postmenopausal women is not a risk factor for periodontal disease
\end{abstract}

\begin{abstract}
ABSTRAK
Polimorfisme genetik IL-1 $\beta$ pada wanita menopause sebagai faktor risiko penyakit periodontal. Penyakit periodontal merupakan penyakit oral dengan etiologi yang multifaktorial serta dapat terjadi pada wanita postmenopause. Tujuan: Penelitian ini bertujuan untuk mengetahui gambaran polimorfisme genetik IL-1 $\beta$ pada populasi wanita postmenopause Indonesia sebagai faktor risiko penyakit periodontal. Metode: Penelitian ini merupakan studi deskriptif menggunakan sampel biologi tersimpan sebanyak 55 buah. Hasil ekstraksi DNA, dilakukan pemeriksaan polimorfisme IL- $1 \beta^{+3954}$ menggunakan metode PCR-RFLP dengan digest enzim restriksi Taq ${ }^{\alpha} 1$ kemudian hasilnya dielektroforesis. Hasil penelitian dianalisis menggunakan tes chi-square. Hasil: Gambaran frekuensi genotipe adalah CC $85,7 \%$, CT 14,3\%, dan TT tidak ada pada orang yang normal. CC $91,7 \%$, CT $8,3 \%$, and TT tidak ada pada orang yang memiliki penyakit periodontal. Simpulan: Polimorfisme genetik IL-1 $\beta$ pada wanita pascamenopause Indonesia bukan merupakan faktor risiko penyakit periodontal
\end{abstract}

Key words: genetic polimorphism, menopause, periodontal disease

\section{PENDAHULUAN}

Penyakit periodontal merupakan penyakit inflamasi kronis yang disebabkan oleh bakteri yang menyerang periodonsium, yaitu jaringan penyangga gigi. ${ }^{1,2}$ Menurut hasil studi morbiditas Surkenas (Survei Kesehatan Nasional) 2003, penyakit gigi dan mulut menduduki urutan pertama dari 10 kelompok penyakit terbanyak yang dikeluhkan masyarakat. Penyakit periodontal merupakan penyakit gigi dan mulut lain yang banyak dikeluhkan selain karies gigi. Berdasarkan SKRT 2004, prevalensi karies adalah $90,05 \%$, sedangkan prevalensi penyakit periodontal $96,58 \%{ }^{3}$
Penyebab utama dari penyakit periodontal adalah mikroorganisme yang berkoloni dan melekat pada permukaan gigi. Koloni bakteri yang dibiarkan akan menjadi plak, yang dapat menyebabkan gingivitis. Bila keadaan berlanjut, inflamasi akan bertambah parah sehingga kerusakan jaringan akan mencapai daerah periapikal. $^{4}$ Mikroorganisme yang menyebabkan penyakit periodontal ini banyak terdapat pada pasien dengan oral hygiene yang buruk. $^{5}$ Penyakit periodontal juga dapat menjadi manifestasi oral dari beberapa penyakit sistemik seperti penyakit kardiovaskular (hipertensi, penyakit jantung iskemik, gagal jantung kongenital, infeksi endokarditis), kelainan endokrin (diabetes mellitus, 
kelainan kelenjar tiroid dan paratiroid, serta kekurangan adrenalin), penyakit ginjal, penyakit hepar, penyakit paru, kemoterapi, terapi radiasi, perdarahan, serta penyakit infeksi (hepatitis, HIV dan AIDS, tuberkulosis)., ${ }^{2,6}$ Tingkat keparahan penyakit periodontal juga tampak lebih besar pada pasien dengan sistem kekebalan tubuh yang rendah, bila dibandingkan dengan pasien yang sehat. ${ }^{7}$ Dalam rongga mulut, terjadinya inflamasi merupakan respon umum dari sistem imun akibat mikroorganisme patogen. ${ }^{2}$ Terjadinya inflamasi dimediasi oleh berbagai faktor. Salah satu faktor proinflamasi yang berperan dalam penyakit periodontal adalah gen IL-1 $\beta$. Peningkatan konsentrasi IL-1 $\beta$ dalam gingival crevicular fluid (GCF) merupakan karakteristik dari penyakit periodontal. ${ }^{8}$ Studi lainnya menunjukkan asosiasi polimorfisme gen IL-1 $\beta$ dengan penyakit periodontitis kronis pada populasi di India Selatan. ${ }^{9}$ Selain studi yang mempelajari hubungan penyakit periodontal dengan penyakit sistemik, banyak pula studi yang mengaitkannya dengan polimorfisme genetik IL-1 $\beta$. Polimorfisme dari periodontitisassociated genotype (PAG) menunjukkan adanya peningkatan kadar IL-1 $\beta$ dalam gingival crevicular fluid (GCF). ${ }^{10}$ Banyaknya studi genetik yang mempelajari hubungan faktor genetik merupakan hal yang penting untuk mengetahui faktor risiko seseorang menderita penyakit periodontal. ${ }^{3}$ Ada empat momen di mana seorang wanita lebih berisiko terhadap penyakit periodontal, yaitu setelah menopause, pubertas, kehamilan, dan saat menstruasi. Pada wanita pascamenopause, hormon estrogen dan progesteron akan berhenti diproduksi, sementara hormon estrogen berperan penting dalam menjaga homeostasis tulang termasuk tulang rahang. Oleh karena itu, pada wanita pascamenopause akan terjadi penurunan densitas tulang rahang, serta membuat jaringan periodontal lebih rentan terhadap bakteri. ${ }^{2,11}$ Saat ini, di Indonesia terdapat 14 juta wanita menopause, dan angka ini diperkirakan akan mencapai 60 juta pada tahun 2025 nanti. ${ }^{12}$ Studi mengenai periodontitis yang banyak terjadi terutama pada wanita terutama bagi yang telah mengalami menopause. ${ }^{13}$ Penelitian ini ditujukan untuk mengetahui gambaran polimorfisme genetik IL-1 $\beta$ pada populasi wanita pascamenopause Indonesia sebagai faktor risiko terjadinya penyakit periodontal.

\section{METODE}

Penelitian ini merupakan penelitian deskriptif dengan analisis laboratoris. Sampel penelitian ini merupakan hasil ekstraksi DNA dari serum darah wanita pascamenopause dan merupakan bahan penelitian tersimpan pada suhu $-20^{\circ} \mathrm{C}$ di Laboratorium Biologi Fakultas Kedokteran Universitas Indonesia. Total sampel yang digunakan berjumlah 55 buah dengan kriteria inklusi wanita pascamenopause yang menandatangani informed consent dan kriteria eksklusi adalah wanita yang masih mengalami menstruasi serta tidak menandatangani informed consent. Sampel DNA direndam di dalam water bath pada suhu kamar selama $\pm 1-2$ menit kemudian di-vortex sampel DNA. Untuk blank, digunakan $500 \mu 1 \mathrm{ddH}_{2} \mathrm{O}$

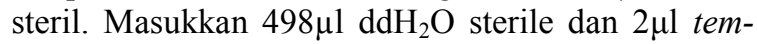
plate DNA dan dilakukan pipetting agar DNA dan $\mathrm{ddH}_{2} \mathrm{O}$ steril tercampur merata. Kuvet dimasukkan ke Spektrofotometer. Kadar kemurnian DNA diukur dengan A 260/280. Larutan Agarose 1,5\% dibuat dengan 0,75gr bubuk Agarose dan 50ml TAE kemudian dipanaskan di dalam microwave oven selama 1 menit dan diaduk dengan orbital shaker (kecepatan $\left.0,75 \mathrm{~min}^{-1}\right)$. Larutan dituang ke dalam cetakan gel yang telah dipasangi sisir untuk well dan diberi duct tape pada kedua sisinya. Masukkan gel ke dalam tangki elektroforesis. Gel sepenuhnya terendam larutan TAE. Sebanyak $3 \mu$ l DNA ladder 50bp (marker) ke dalam well pertama. Untuk $5 \mu \mathrm{l}$ DNA dicampur dengan $2 \mu \mathrm{l}$ loading dye pada kertas parafilm dimasukkan ke dalam well berikutnya. Elektroforesis dilakukan pada setting $80 \mathrm{~V}, 400 \mathrm{~mA}$ selama 60 menit. Setelah dielektroforesis, rendam gel dalam larutan Ethidum bromide (EtBr) yang telah diencerkan $(50 \mu \mathrm{l}$ EtBr dan 50ml Aquadest) lalu biarkan selama 5 menit dan dihindari dari sinar matahari. Gel dicuci dengan air mengalir selama 15 menit. Analisis foto dilakukan dengan cara memasukkan gel ke dalam GelDoc.

Untuk amplifikasi DNA teknik PCR, digunakan Primer IL-1 $\beta+3954$ Forward 5'-CTC AGG TGT CCT CGA AGA AAT CAA A-3' dan Reverse 5'GCT TTT TTG CTG TGAG TCC CG-3'. Komposisi setiap $25 \mu \mathrm{l}$ reaktan mengandung $12,5 \mu \mathrm{l}$ taq polymerase, $0,5 \mu 1$ primer forward, $0.5 \mu$ l primer reverse,

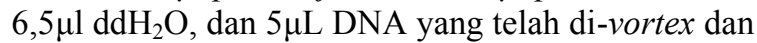
di-centrifuge. Kondisi PCR meliputi 35 siklus, diawali dengan denaturasi awal (initial denaturation) suhu $94^{\circ} \mathrm{C}$ selama 5 menit (1 siklus), lalu denaturasi (denaturation) suhu $94^{\circ} \mathrm{C}$ selama 30 detik, annealing suhu $58^{\circ} \mathrm{C}$ selama 30 detik, ekstensi (extension) suhu $72^{\circ} \mathrm{C}$ selama 30 detik, ekstensi akhir (final extension) suhu $72^{\circ} \mathrm{C}$ selama 7 menit, dan penyimpanan (final hold) suhu $4^{\circ} \mathrm{C}$. Hasil PCR diperiksa dengan elektroforesis menggunakan Agarose $1,5 \%$ yang diatur pada $80 \mathrm{~V}, 400 \mathrm{~mA}$ selama 60 menit dengan ladder $50 \mathrm{bp}$ dan $7 \mu \mathrm{l}$ produk PCR. Hasil elektroforesis direndam EtBr selama 5 menit dan dicuci dengan air mengalir selama 15 menit dan dianalisis dalam GelDoc. Produk PCR yang dihasilkan dari amplifikasi DNA adalah 194bp. Pemotongan produk PCR dilakukan dengan pemberian enzim restriksi Taq ${ }^{\alpha} 1$ dengan komposisi $\mathrm{Taq}^{\alpha} 10,5 \mu \mathrm{l}, \mathrm{Bo}$ vine Serum Albumin (BSA) $1 \mu \mathrm{l}$, Buffer $2 \mu \mathrm{l}$, $\mathrm{ddH}_{2} \mathrm{O}$ $17,5 \mu \mathrm{l}$, dan produk PCR $10 \mu \mathrm{l}$. Produk enzim diinkubasi dengan water bath pada suhu $65^{\circ} \mathrm{C}$ selama 4 
jam, lalu dipindahkan ke suhu $85^{\circ} \mathrm{C}$ untuk diinaktivasi. Hasil pemotongan diperiksa menggunakan elektroforesis dengan 3\% Agarose dan buffer TAE. Produk enzim sebanyak $10 \mu \mathrm{L}$ dicampur dengan loading dye sebanyak 2 dan ladder yang digunakan adalah $25 \mathrm{bp}$. Elektroforesis digunakan pada tegangan $80 \mathrm{~V}, 400 \mathrm{~mA}$ selama 60 menit. Untuk visualisasi DNA, gel ditempatkan pada GelDoc. Data kemudian dianalisis menggunakan program komputer Statistical Program for Social Science (SPSS) versi 17.

\section{HASIL}

Pada data sekunder terdapat data OHIS dan PBI yang digunakan untuk mengetahui apakah sampel berisiko terkena penyakit periodontal atau tidak. Prevalensi penyakit diabetes pada 55 sampel di mana 48 $(87,3 \%)$ diantaranya menderita penyakit periodontal. Produk PCR yang dihasilkan dari amplifikasi DNA adalah 194bp dengan DNA ladder yang digunakan adalah 50bp. Pemotongan produk PCR dilakukan dengan pemberian enzim restriksi $\mathrm{Taq}^{\alpha} 1$. Hasilnya adalah 194bp dan menunjukkan foto hasil elektroforesis hasil pemotongan gen IL-1 $\beta^{+3954}$ dengan enzim restriksi $\mathrm{Taq}^{\alpha} 1$ di mana potongan yang diperoleh adalah $97+85+12$ bp untuk CC, $182+12$ bp untuk CT. Hasil menunjukkan untuk frekuensi alel $\mathrm{C}$ adalah 92 dari 96 alel $(95,8 \%)$ dan $\mathrm{T}$ adalah 4 dari 96 alel $(4,2 \%)$ pada orang dengan risiko penyakit periodontal dan $\mathrm{C}$ adalah 13 dari 14 alel $(95,3 \%)$ dan $\mathrm{T}$ adalah 1 dari 14 alel $(4,7 \%)$ pada orang yang tidak berisiko penyakit periodontal. Hasil perhitungan tes chisquare $(p=0,508)$ menunjukkan hasil yang tidak bermakna untuk polimorfisme genetik IL- $1 \beta^{+3954}$ pada wanita postmenopause Indonesia.

\section{PEMBAHASAN}

Penelitian ini secara umum bertujuan untuk menjelaskan gambaran polimorfisme genetik sebagai faktor risiko terjadinya penyakit periodontal dengan mendeteksi gen IL-1 $\beta$ pada populasi wanita pascamenopause Indonesia yang mengalami metilasi. Pada penelitian ini data yang digunakan merupakan data sekunder yang tersimpan pada laboratorium Biologi Fakultas Kedokteran Universitas Indonesia. Skor PBI yang digunakan untuk menggambarkan keadaan periodontal pada wanita pascamenopause dapat dipengaruhi oleh faktor fluktuasi dari hormon reproduksi menjelang menopause dapat menimbulkan inflamasi pada jaringan periodontal, sehingga perdarahan pada saat probing dapat terjadi. ${ }^{25}$ Studi sebelumnya menyatakan bahwa pengukuran skor OHIS dan PBI dapat digunakan untuk menggambarkan keadaan dan penyakit periodontal pada umumnya. ${ }^{45}$ Produk hasil PCR akan tampak pada 194bp. Pada genotipe homozigot TT, tidak ada pemotongan produk PCR yang terjadi dan hanya band 194bp yang terlihat. Berdasarkan teori, ada 3 genotipe yang berbeda, yaitu CC, CT, dan TT. ${ }^{9}$ Studi yang dilakukan oleh Prakash et al menyatakan bahwa persentasi penyakit periodontal pada grup alel $\mathrm{T}(28 \%)$ lebih tinggi daripada grup alel $\mathrm{C}$ $(8,7 \%)$. Namun, pada penelitian ini tidak ditemukan sampel dengan genotipe TT. Pada genotipe homozigot CC, produk PCR ter-digest pada 97, 85, dan $12 \mathrm{bp} .{ }^{9}$ Namun, pada penelitian ini hanya terlihat 2 band, yaitu 97bp dan 85bp.

Pada genotipe heterozigot CT, produk PCR terdigest pada 182 dan $12 \mathrm{bp} .{ }^{9}$ Pada penelitian ini terlihat satu pita, yaitu pada 182bp. Berdasarkan hasil perhitungan, ditemukan genotipe $\mathrm{CT}$ sebanyak 1 dari 12 orang $(8,3 \%)$ pada orang dengan risiko penyakit periodontal dan sebanyak 4 dari 43 orang $(9,3 \%)$ pada orang yang tidak berisiko diabetes. Pada penelitian di Hungaria, ditemukan genotipe CT pada anakanak dengan DM tipe 1 sebanyak 170 dari 312 orang (54\%) dan pada anak-anak sehat sebanyak 62 dari 171 orang $(36 \%)$. ${ }^{9}$ Frekuensi alel $\mathrm{C}$ adalah 92 dari 96 alel $(95,8 \%)$ dan T adalah 4 dari 96 alel (4,2\%) pada orang dengan risiko penyakit periodontal dan $\mathrm{C}$ adalah 13 dari 14 alel (95,3\%) dan T adalah 1 dari 14 alel $(4,7 \%)$ pada orang yang tidak berisiko penyakit periodontal. Berdasarkan hasil perhitungan, frekuensi genotipe adalah CC $85,7 \%$, CT 14,3\%, dan TT tidak ada pada orang yang tidak memiliki penyakit periodontal dan CC $91,7 \%$, CT $8,3 \%$, and TT tidak ada pada orang yang memiliki penyakit periodontal. Hal ini tidak sesuai dengan literatur bahwa alel CC merupakan homozigot normal, sedangkan alel CT dan TT diduga mempunyai kaitan dengan penyakit periodontal. ${ }^{9}$ Hasil penelitian ini menunjukkan perbedaan yang tidak bermakna frekuensi genotipe CC antara sampel penderita penyakit periodontal dengan yang tidak. Hasil tes chi square $(p=0,508)$ menunjukkan hasil polimorfisme genetik IL-1 $\beta$ bukan merupakan faktor risiko untuk penyakit periodontal pada wanita paska menopause Indonesia.

\section{SIMPULAN}

Kesimpulan yang dapat diambil dari penelitian ini adalah bahwa polimorfisme genetik IL-1 $\beta$ terjadi dengan hasil potongan 97,85 , dan $12 \mathrm{bp}$ untuk genotipe $\mathrm{CC}$ dan potongan 182 dan $12 \mathrm{bp}$ untuk genotipe CT. Polimorfisme genetik IL- $1 \beta$ bukan merupakan faktor risiko untuk penyakit periodontal pada wanita paska menopause Indonesia.

\section{DAFTAR PUSTAKA}

1. Neville, et al. Periodontal diseases. In: Oral and Maxillofacial Pathology. 3rd ed. St. Louis: Saun- 
ders Elsevier; 2009. p. 154.

2. Newman MG. The Normal Periodontium. In: Newman MG, Takei HH, Carranza FA, editors. Carranza's Clinical Periodontology. 9th ed. Philadelphia: Saunders; 2003. p. 16.

3. Situmorang N. The impact of dental caries and periodontal disease in quality of life, a study in two sub-districts in Medan municipality. [disertasi] Universitas Indonesia, Jakarta; 2004. Indonesian.

4. Loesche W. Dental caries and periodontitis: Contrasting two infections that have medical implications. Inf Dis Clin North Am. 2007;21:471.

5. Kardum MI, Živko-Babić J, Tomljenović A. The effect of anticorrosive chemical factors on periodontal health. University of Zagreb, School of Dental Medicine, Zagreb, Croatia: Acta Stomatol Croat. 2007;41:241-50.

6. Susanto H, Nesse W, Dijkstra PU, Agustina D, Vissink A, Abbas F. Periodontitis prevalence and severity in Indonesians with type 2 diabetes. J Periodontol; 2010.

7. Noble JM, Borrell LN, Papapanou PN, Elkind MS, Scarmeas N, Wright CB. Periodontitis is associated with cognitive impairment among older adults: analysis of NHANES-III. J Neurol Neurosurg Psychiatry. 2009;80:1206-11.

8. Figueredo CMS, Ribeiro MSM, Fischer RG, Gustafsson A. Increased interleukin-1 $\beta$ concentration in gingival crevicular fluid as a characteristic of periodontitis. J Periodontol. 1999;70:1457-63.

9. Prakash PSG, Victor DJ. Interleukin-1 $\beta$ gene polymorphism and its association with chronic periodontitis in South Indian population. International J Genet Mol Biol. 2010;2:179-83.

10. Engebretson SP, Lamster IB, Herrera-Abreu M, Celenti RS, Timms JM, Chaudhary AG, et al. The influence of interleukin gene polymorphism on expression of interleukin-1beta and tumor necrosis factor-alpha in periodontal tissue and gingival crevicular fluid. J Clin Periodontol. 1999;70:567-73.

11. Haas AN, Rösing CK, Oppermann RV, Albandar JM, Susin C. Association among menopause, hormone replacement therapy, and periodontal attachment loss in southern Brazilian women. J Periodontol. 2009;80:1380-7.

12. Prayitno SW. The association between biodata and periodontal status among young adult Indonesians. In: Risk Factors in Asian Pacific Populations. Australia; 1996:22-8.

13. Novak MJ. Classification of disease and conditions affecting the periodontium. In: Newman MG, Takei HH, Carranza FA, editors. Carranza's Clinical Periodontology. 9th ed. Philadelphia: Saunders; 2003. p. 64-72.

14. Samaranayake LP. Essential microbiology for dentistry 2nd ed. Churchill Livingston; 2002 WHO. Epidemiology, Etiology and Prevention of Periodontal Disease. Geneva. p. 7-9.

15. Anastasia S. Buku ajar periodonti. Jakarta: Hipokrates; 1993. p. 95-104. Indonesian.

16. Netea MG, Simon A, Van de Veerdonk F, Kullberg B-J, Van der Meer JWM, Joosten LAB. IL$1 \beta$ processing in host defense : beyond the inflammasomes. PLoS Pathog. 2010;6:e1000661.

17. Causi S, Santolo M, Casabellata G, Ryckman K, Williams SM, Guaschino S. Association of interleukin-1 $\beta$ and interleukin-1 receptor antagonist polymorphisms with bacterial vaginosis in non pregnant Italian women. J Periodontol; 2010.

18. Peter F, Fedi J, Vernino AR, Gray JL. The Periodontic Syllabus. 4th ed. Philadelphia: Lippincott Williams and \& Wilkins; 2000. p. 1-13.

19. Holmstrup P. Anatomy of the Periodontium. In: Wilson TG, Kornman KS, editors. Fundamentals of Periodontics. 2nd ed. Chicago: Quinstessesnce; 2003. p. 21-37.

20. Herijulianti E, Indriani TS, Artini S. Pendidikan kesehatan gigi. Jakarta: Penerbit Buku Kedokteran EGC;2002. Indonesian.

21. US Census Burreau [Internet]. Statistics by country for periodontitis [cited 2010 Nov 9]. Available from: http://www.cureresearch.com/p/ periodontitis/stats-country.htm

22. Praju SM. Hubungan gambaran diri dengan tingkat kecemasan ibu masa menopause. USU erepository; 2008. Indonesian.

23. Tezal M, Wactawski-Wende J, Grossi SG, Dmochowski J, Genco RJ. Periodontal disease and the incidence of tooth loss in postmenopausal women. Department of Oral Biology, University at Buffalo, Buffalo, NY, USA. J Periodontol. 2005;76:1123-8.

24. Aschkenazi S, Naftolin F, Mor G. Menopause, sex hormones and the immune system, Menopause Manag. 2000;9:6.

25. Abbas AK, Lichtman AH, Pober JS. Celluler and molecular immunolgy. 4th ed. Philadelphia: WB Saunders; 2000. p. 235-69.

26. Bellanti, Joseph A. Immunology III. W. B. Philadelphia: Saunders company; 1985.

27. Janeway, Charles AT, Paul W, Mark S. Immunobiology. Mark; 2001.

28. Baratawidjaja KG. Imunologi dasar. Ed. Ke-7. Jakarta: Balai Penerbit FKUI; 2006. Indonesian.

29. Campbell L, Keene S. A look at periodontal disease, the contrasting referral approaches of general dentists to periodontal specialists and how it affects the duties and ethics of dental hygienists. The Internet J Dent Sci. 2009:7.

30. Smirnova MG, Kiselev SL, Gnuchev NV. Role of the pro-inflammatory cytokines tumor necrosis factor-alpha, interleukin-1 beta, interleukin-6 and interleukin- 8 in the pathogenesis of the otitis media with effusion. Eur Cytokine Netw. 
2006; 13:161-72.

31. Teles RP, Gursky LC, Faveri M, Rosa EA, Teles FRF, Feres M, et al. Relationships between subgingival microbiota and GCF biomarkers in generalized aggressive periodontitis. John Wiley \& Sons A/S; 2010.

32. Causi S, Di Santolo M, Casabellata G, Ryckman $\mathrm{K}$, Williams SM, Guaschino S. Association of interleukin-1 $\beta$ and interleukin-1 receptor antagonist polymorphisms with bacterial vaginosis in non pregnant Italian women. Mol Hum Reprod. 2007; 13:243-50.

33. Müller HP, Barrieshi-Nusair KM. A combination of alleles 2 of interleukin (IL)-1 $\mathrm{A}^{-889}$ and IL$1 \mathrm{~B}^{+3954}$ is associated with lower gingival bleeding tendency in plaque-induced gingivitis in young adults of Arabic heritage. SpringerVerlag; 2007.

34. Cullinan MP, Westerman B, Hamlet SM, Palmer JE, Faddy MJ, Lang NP, et al. A longitudinal study of interleukin-1 gene polymorphisms and periodontal disease in a general adult population. J Clin Periodontol. 2001;28:1137-44.

35. Ford EB. Genetic polymorphism. London: Faber \& Faber; 1965.

36. Bruce Carlson. SNPs - A Shortcut to Personalized Medicine. Genetic Engineering \& Biotechnology News: Mary Ann Liebert, Inc; 2008.

37. Brown TA. Gene Cloning and DNA Analysis. 4th ed. Blackwell Science; 2001.

38. Gustafsson A, Ito H, Asman B, Bergstrom K. Hyper-reactive mononuclear cells and neutrophils in chronic periodontitis. J Clin Periodontol. 2006;DOI: 10.1111/j.1600-051X.2005.00883.x.

39. Guimarães ALS, De Sá AR, Victória JMN, Correia-Silva JF, Pessoa PS, Diniz MG, et al. Association of interleukin-1 $\beta$ polymorphism with recurrent aphthous stomatitis in Brazilian individuals. Willey online Library; 2006.

40. Dashash M, Drucker DB, Hutchinson IV, Bazrafshani MR, Blinkhorn AS. Interleukin-1 receptor antagonist gene polymorphism and gingivitis in children. Willey online Library; 2006.

41. NCBI [Internet]. [cited 2010 Nov10]. Available from: NCBI Entrez Protein \#CAA39671.

42. Bruce A, Johnson A, Lewis J, Raff M, Roberts K, Walters P. Molecular Biology of the Cell 4th ed. New York and London: Garland science; 2002.

43. Kresno SM. Imunologi: diagnosis dan prosedur laboratorium. Edisi III. Jakarta: Balai Penerbit Fakultas Kedokteran Universitas Indonesia; 1996:3-41. Indonesian.

44. Lange DE. Frequency, seriousness, and treatment needs in periodontal diseases. ZWR. 1986;95:402-6. 